\title{
Drug Testing: What are the Rights of EMPLOYEeS, EMPLOYERS, AND UNIONS?
}

\author{
Sharon L. Oswald \\ Allison Harrison \\ William Woerner \\ Auburn University \\ Auburn, Alabama
}

Drug abuse in the United States has been a commonly recognized problem in the workplace for nearly two decades. A joint study by the National Council of Alcoholism and the Research Triangle Institute suggested that the cost of substance abuse to the American economy ranges from $\$ 60$ to $\$ 145$ billion annually [3]. A 1985 American Management Association study found that approximately 93 percent of all organizations surveyed faced employee drug abuse problems [21]. With the problem so pervasive, it is not surprising that as many as 168 Fortune 500 companies have implemented some form of substance abuse screening or testing; and many more have plans to adopt such policies [3].

From a union-management standpoint, most collective bargaining agreements include rules providing disciplinary action for use and abuse of drugs; however, issues pertaining to drug usage and drug testing have only recently become components of collective bargaining agreements. While it is obviously in the best interest of both the employer and the employee to identify substance abuse problems, strong opposition to drug testing of employees continues to exist. The purpose of this paper is to examine recent interpretations of the law affecting drug testing, particularly where labor unions are involved, and to assess the implications for employers with collective bargaining agreements who wish to institute or continue the use of drug testing.

\section{The Drug Problem and Drug Testing}

Drug abuse is related to low productivity; absenteeism; and, in some cases, increased sick leave; drug-related injury; increased health benefit costs; increased worker compensation payments; and increased costs for overtime, training, retraining, and security [3]. The use of drugs is also believed to compromise workplace safety, an issue that employers are restricted by law to insure. A National Institute on Drug Abuse (NIDA) study reported that on-the-job drug and alcohol abuse by auto workers alone costs an estimated $\$ 175$ per vehicle in lost productivity and increased injury claims [33].

It is estimated that the drug testing market in the United States has reached approximately $\$ 230$ million. In the Transportation Department alone, random drug testing of the four million workers is expected to cost approximately 13 million in 1990; but savings in terms of fewer accidents and absentee hours are projected to be 
in the billions of dollars over the next ten years [11].

Federal support of drug testing came on September 15, 1987, when President Reagan issued an executive order for a drug-free federal workplace. As a result, the Drug Free Workplace Act of 1988 requires employers holding government contracts of $\$ 25,000$ or more to meet six criteria in an effort to provide a drug-free workplace. Later that same year, the Department of Defense established regulations requiring employers who seek or enter into contracts with the Department of Defense to include an additional clause guaranteeing that drug tests will be conducted on all employees in positions relating to national security or protecting the health and safety of others.

\section{Drug Testing and the NLRB}

In November 1987, the National Labor Relations Board (NLRB) issued its position on drug-testing programs. A memorandum generated by Rosemary Collyer, NLRB General Counsel, stated that a company has an obligation under federal law to bargain with the union before unilaterally implementing a required drug-testing program. The NLRB's position was based on an employer's duty to bargain over wages, hours, and terms or conditions of employment as stated in the National Labor Relations Act (NLRA). For example, the adverse effect of drug testing may result in disciplinary action and therefore would affect the terms and conditions of employment [14]. The following points were stressed in the NLRB ruling: (1) drug testing for current employees and job applicants is a mandatory subject of bargaining; (2) implementation of a drug-testing program is a substantial change in working conditions, even if established work rules previously banned the use and possession of drugs in the plant.

AMOCO Oil Company's drug-testing policy was challenged by the Oil, Chemical and Atomic Workers Union in 1987 because it was not part of a collective bargaining agreement. The primary concem on the union's part was whether the employees would be protected from arbitrary and capricious actions on the part of management. While both sides consented to have an arbitrator determine whether the drug-testing policy must be considered by the joint labor-management health and safety committee, AMOCO implemented the program prior to arbitration. The union, under three separate actions (Utah, North Dakota, and Wyoming), sought to enjoin the drug-testing practice pending arbitration. Only the Utah court upheld the union's demand. Collyer's November memorandum made arbitration a moot point [38].

Drug testing as a part of the pre-employment examination has been questioned on two counts. First, Title VII advocates suggest that pre-employment testing is a selection device; and, therefore, drug tests must be statistically validated if used as a pre-employment screening tool [13]. Another concern arose when unions argued that pre-employment testing should be a mandatory bargaining issue. If an applicant must successfully complete a drug test in order to be hired, then drug testing again becomes a condition of employment.

In two decisions during June of 1989 , the NLRB clarified the question of mandatory bargaining issues in the implementation of substance-abuse testing programs [16]. In the Star Tribune [28] and Johnson-Bateman Company [17], the NLRB found 
that employers must bargain over the establishment of drug and alcohol testing programs, as defined by the National Labor Relations Act. The decisions were based on the fact that the creation and implementation of such programs clearly represent changes in terms and conditions of employment. Pre-employment testing was not considered a mandatory bargaining issue since applicants are not considered "employees" by the Act.

\section{Company Rules and Reasonable Cause}

Testing procedures can be classified in five general categories. Pre-employment testing, as previously discussed, involves the testing of applicants seriously considered for employment or who have been offered employment positions. In a survey of private employers, Way [35] found that half of all organizations surveyed utilized preemployment drug testing. Random testing occurs when employees are unaware of who will be tested, when they will be tested, or the frequency of the testing. Fitness-forduty testing involves the periodic testing of employees, generally occurring with their annual physical examinations. For-cause testing requires an employee to be tested following certain on-the-job accidents or incidents. Suspicion-based testing requires the employer to show reasonable suspicion prior to subjecting the employee to substance-abuse testings [3]. For the employer to meet the "reasonable suspicion" clause, certain behavioral or physical indications of drug abuse must be identified by the employer. Physical indicants may include reddening of the eyes, perspiration and nausea. Behavioral signs may include euphoria, anxiety, suspicion, and paranoia [10]. In the absence of a well-defined drug testing policy, arbitrators may be asked to decide whether administering the test could be construed as arbitrary, discriminatory, or retaliatory [8]. These issues usually emerge when testing is left up to the discretion of the supervisor.

Denenberg and Denenberg [8] reported that much of the arbitrator's decision is based on an examination of the principles of selection that govern the testing program. Most testing programs are categorized as either random or suspicion-based testing. Yet, according to Verespej [34], in over a dozen cases courts have found random drug testing to be unconstitutional and that there must be "reasonable suspicion or probable cause" to test employees.

Defining "reasonable cause" is another gray area in suspicion-based drug testing. Koven and Smith [19] support the use of the set of seven just-cause standards universally accepted by arbitrators as a guideline for hearing cases. Denenberg and Denenberg [8] further found that in contracts where drug testing is stated to take place only "upon just and sufficient cause," the employer must prove impairment by "observing overt behavior or conduct of the employee relative to his job that establishes probable cause that the employee is under the influence of alcohol or drugs." A drug policy could state that reasonable cause "shall include, but not be limited to, management's personal observation of an employee's appearance, behavior, or speech." For example, the United States Court of Appeals for the Third Circuit upheld the Philadelphia police department's right to test on "reasonable suspicion" and terminate 
an officer based on drug test results. The court said there was "reasonable grounds" to suspect the officer of drug use based on a fellow officer's accusation and an earlier incident in which the grievant was found in the company of another officer who was allegedly selling drugs [5].

Other cases have found that statistical indications, such as excessive absenteeism or tardiness, may not qualify as reasonable cause. The question arises, is there one appropriate standard for arbitrators to follow in drug-related cases? Generally in a discharge case the arbitrator uses the standard "a preponderance of evidence." Wynns [37] stated that in cases involving violation of the criminal code, it has been suggested that arbitrators should hold employers to a "beyond a reasonable doubt" standard of proof.

Random drug testing has also become a controversial issue. Some collective bargaining agreements contain provisions limiting testing to situations in which reasonable cause exists. In the 1986 National Football League Players Association case, management's attempts to impose a random-testing program were denied because such testing was not part of the contract clause defining drug testing. The decision suggests that if an established drug-testing program is limited to reasonable cause, employers will not be able to expand the scope of testing under the management rights argument [9].

In Phelps Dodge Copper Products Company [25], Arbitrator Albert Blum ruled that the company could not expand the existing drug-control policy to include random testing without bargaining with the union, even though the union had acquiesced in many other rules and rule changes involving mandatory bargaining issues. Blum further stated that the company's action went beyond "expressions of residual managerial power evidenced in other rules."

\section{Refusal of Testing}

Another area of controversy in drug testing involves discharge of an employee for refusing to submit to a test. If the collective bargaining agreement lacks specific provisions regarding testing, some arbitrators will not uphold a discharge for refusing a management order to take a drug test. In some cases, charges of insubordination for refusal to take a drug test were not upheld if the employer failed to show either that drugs caused problems in the plant or that the employee displayed signs of drug use. Invasion of privacy becomes an issue if the employer attempts to force an employee to submit to a drug test without probable cause [8]. Attempts were made to clarify the probable cause issue in American Standard [1], where the arbitrator held that the company must present clear and convincing evidence of the employee's intoxication. In other cases, failure to specify the penalty for refusal to submit to a drug test has been grounds for arbitrators to reinstate grievants [14].

In Material Service Corporation [22], because the company did not have a valid drug policy, Arbitrator James Cox found that the employer did not have just cause to discharge an end-loader operator who refused to take a drug test after the supervisor allegedly smelled marijuana in the cab. While the company had previously discussed 
a drug policy with the union, no agreement had been made at the time of the incident. Even in the absence of a stated policy, the company argued that they had the right to give a "reasonable cause" type test. Cox disagreed on the grounds that the employee was not in a "safety sensitive" position.

\section{The Privacy Issue}

The emphasis on privacy has also become an important issue in arbitration. More specifically noted is the question of whether drug testing is a violation of Fourth Amendment rights.

The Fourth Amendment to the Bill of Rights protects individuals from unreasonable searches and seizures of the individual's self, homes, papers, and effects. The amendment also states that search and seizure can only be conducted when probable cause exists and a warrant describing the person or place to be searched has been issued. In terms of how the Fourth Amendment applies to drug testing, several questions must be addressed. Is a drug test a search and seizure; and, if so, is it legal? Is a drug test unreasonable? Is there probable cause for the drug test?

Several cases have addressed the issue of drug testing in the context on the Fourth Amendment. For example, in a Northern Illinois District Court case, Judge Susan Getzendanner held that the Fourth Amendment does not permit the requirement of all employees to submit to mandatory screening without reasonable suspicion of illegal drug use. In the case involving employees of the Cook County Department of Corrections, Judge Getzendanner decided that compulsory urination and testing of the urine samples are considered searches and are subject to Fourth Amendment scrutiny. She added that the evidence was not such that drug problems in the Corrections Department were so pervasive that they could not be handled with less intrusive means [30]. Likewise, a New York State appeals court ruled against a New York City police department mandate for random drug testing of officers, again indicating that random drug testing without reasonable suspicion violated the members' rights under the Fourth Amendment. The court, however, did not object to drug screening or drug testing as a part of the annual employee physical [6].

In Texas Utilities Generating Company, Arbitrator Samuel Edes [31] found that the company improperly required the grievant to submit to drug testing. In this case, the grievant returned to work after his shift with two fellow employees. The grievant and the two employees were in possession of marijuana and had left some in the ashtray of the grievant's car. The grievant declined a drug test. Edes reasoned that the grievant was not on company premises as an employee; therefore, the company was not permitted to test for any activities outside of the work relationship, again deeming this an invasion of privacy.

The New York Court of Appeals held in Patchoque-Medford Congress of Teachers v. Board of Education of the Patchoque-Medford Union Free School District [24] that the school district's drug-testing plan was unconstitutional because it represented an unreasonable search and seizure. The Court said the district needed reasonable suspicion that the teachers were using drugs before they could be tested. It further 
stated that searches were intended to serve the public interest, but in doing so should not undermine the public's interest in maintaining the privacy, dignity and security of its members.

Another aspect of the privacy issue revolves around requiring human observation to ensure the specimen is that of the subject in question [15]. This was a primary consideration in rejecting the Patchoque-Medford drug-testing program. The court stated that this was "at least as intrusive as a strip search," and should not be permissible without reasonable suspicion of drug use.

As early as 1966, in Schmerber v. California [26] the courts found the use of the body's blood for determining alcohol content constituted a Fourth Amendment search. As recently as 1989, in Skinner v. Railway Labor Executives Association [27], the Supreme Court reaffirmed the Schmerber decision. The Court, however, found the Skinner search to be reasonable despite the absence of individual suspicion. The search was deemed reasonable for a variety of reasons. The intrusive nature of drug testing was minimized by sample collection in a medical environment, absent any observers. Also, the results of the tests were found to be treated in a confidential manner. The Court concluded its justification for determining the search reasonable by explaining that employees who chose to work in a regulated industry where safety is crucial should expect a reduction in their privacy. Specifically, Supreme Court Judge Kennedy stated that in issues concerning safety, the individual's interests were diminished by the United States Governments' "compelling" interest in a safe environment.

In a second landmark decision, National Treasury Employees Union v. Von Raab [23], a testing program for the United States Customs Service, which called for testing of all employees who applied for or performed jobs requiring such duties as drug interdiction, carrying of firearms, and handling classified information, was upheld by the Supreme Court. The point of interest in this case was that the Customs Service had little evidence of an existing drug problem. In fact, only 5 of 3,600 employees tested positive for drugs. The Court found drug testing to be a reasonable search and therefore lawful, due to the governments' compelling interest in the societal problems caused by drugs and drug smuggling.

Since the Von Raab and Skinner decisions, the Court has refused to hear drugtesting cases claiming Fourth Amendment violations. This refusal is indicative of the Court's position that not all Fourth Amendment searches will be viewed as illegal. One point of clarity is that the Fourth Amendment is not applicable to private employers unless their actions are in response to government-mandated testing programs, as established by the Drug Free Workplace Act of 1988.

While the Skinner and Von Raab decisions are not directly applicable to private employers, they appear to have some implications for parties interested in defining a reasonable drug testing program. Both programs were specific and carefully managed, and both were implemented for employees in sensitive jobs. The Von Raab decision makes it clear that an existing problem is not needed to justify a drug testing program.

Interestingly, in a 1988 case, Stone Container Corporation [29], Arbitrator Richard Ross suggested that it was not necessarily the arbitrator's place to determine the 
reasonableness of the drug test but; rather to be concerned with the appropriate implementation of the test as it relates to employee rights.

\section{Faulty Test Findings}

Questionable findings on drug tests have been another issue closely examined by the courts, as well as arbitrators. Much of the concern revolves around faulty testing procedures. In Jones $\mathrm{v}$. McKenzie [18] the employee submitted to a urinalysis test for drugs as part of the employer's testing program. The first test resulted in a positive reading. The test was repeated a second time and again gave a positive reading. The employee agreed to two additional tests both of which registered negative. Despite the latter results, the employee was terminated. The district court ruled that the second test was merely a repeat of the first and that an alternative method should have been employed. This was supported by the drug test manufacturer's label warning that "positive results should be confirmed by an alternative method."

There is also a possibility of a Title VII violation as a result of false positives on drug tests. False positives may be caused by dark skin color. If the employee or applicant failing the drug test is dark skinned, he/she may have valid grievances on the basis of race or color [8].

Other sources of false positives can include over-the-counter drugs such as Contac, Sudafed, aspirin; some foods and beverages, such as poppy seeds and herbal teas; and highly concentrated urine specimens [8].

Due to the possibility of false positive results, the arbitrator is faced with deciding whether a positive test result should be relied upon as the sole or major piece of evidence against a grievant. The arbitrator must decide whether the positive result proves impairment and thus was discipline justified. Denenberg and Denenberg [8] suggest that the issue may be whether the totality of the evidence, not merely the test result, justifies the discipline. According to Wilson [36], employers should be forced in arbitration to prove: (1) the illegal identity of the drug allegedly found; (2) that the employee was in fact "high;" (3) while on the job; (4) that this impaired job performance; and (5) that the lab that analyzed the specimen properly identified it as belonging to the disciplined worker, that the procedure used was reliable, and that the technicians were competent. Additionally, Wilson suggested that the grievant should be permitted to introduce his or her own independent test results.

\section{Other Legal Concerns}

There are a number of legal issues surrounding urine testing which are being considered in arbitration hearings. Gampel and Zeese [12] listed the following:

Confirmation Testing. It is necessary for urine tests to be confirmed because of problems in the chemistry that might arise. Legally, the only acceptable type of test is a gas chromatography/mass spectometry.

Relationship to Employment. Urine tests do not measure impairment. The tests will provide employers with information about a person's drug use; however, with the 
exception of marijuana, no research studies have confirmed that drug use outside of the work environment impacts on-site work performance. Because urine tests do not measure impairment or the ability to perform a job, a positive result from a drug test is considered to be unrelated to employment. According to Gampel and Zeese [12], arbitrators have awarded employees their jobs back on this point. In fact, in the last ten years as many as two-thirds of the drug-related discharges cases arbitrated were overturned and the employee reinstated [4].

In Union Plaza Hotel [32], the Arbitrator ruled that the employer needed to show that the employee failing the drug test was under the influence at work. Further, if the employer chooses discharge as the proper disciplinary action, the employer needs to show that the employee failing the drug test was under the influence while at work [1].

Violation of Employment Contract. Many labor agreements have contract language concerning drug use, and most forbid on-the-job intoxication. A positive urine test is not proof of violation of any of these items; and, according to Gampel and Zeese [12], many arbitrators have reinstated employees on this issue.

Another legal issue arbitrators must resolve is to what extent the legal status of the drug should effect the arbitration award. Should, for example, the "decriminalization" of a drug, such as marijuana, take away from the employer's ability to impose discipline upon an employee involved with the drug. The following are two arbitral views as reported by Denenberg [7]: (1) "The arbitrator is mindful that there is a growing tolerance of marijuana, and that there may be further decriminalization. But at this point the arbitrator cannot very well say the company did not have proper cause to discharge the grievant merely because it does not choose to adopt a permissive view of grievant's conduct." (2) "The company's right to discharge for marijuana use is fully recognized. However, the arbitrator does find that the company has the responsibility to consider this factor, i.e., the decriminalization, as well as the employee's overall record and his length of service in determining the appropriateness of the penalty. . . . It must be concluded that although the grievant clearly violated the company rule concerning use of marijuana, the company's summary discharge was not for just and sufficient cause."

Obviously, a consensus approach does not exist dealing with drug arbitration cases. For example, in Kroger Company [20] a worker discharge was overturned because the employee's work performance did not appear to suffer despite evidence of cocaine in his bloodstream. While in another case, just the presence of marijuana was enough evidence to uphold a termination. Other issues, such as not being able to distinguish between the use of on and off premise drug use as a result of a drug test, have been cited, as in the case of CFS Continental Inc. [2], as reason to overturn a termination.

\section{Conclusion}

As the limitations on drug testing are being questioned in both the courts and the arbitration arena, the rights of employees and employers are in a state of constant change. One thing is clear, there is less tolerance today than ever before for drug 
abuse, particularly in jobs deemed "sensitive" in nature. Thus, the trend is toward mandatory testing of employees in jobs where safety or security is an issue.

To date, the rulings of arbitrators and the courts can be summarized in four major points:

1. Employers must bargain with the union prior to implementing a drug-testing program for the purpose of discipline but not for the purpose of pre-employment testing.

2. Suspicion-based drug-testing programs have been viewed more positively by the courts and arbitrators; random testing has been given approval for safety-sensitive jobs.

3. Drug testing is not considered to be an illegal search or seizure as long as it is conducted within reasonable procedures and guidelines.

4. Off-site drug use, unless it is proven to have detrimental effects on the employee's work, cannot be questioned by the employer.

While some clarification as to the rights of employees, employers, and unions has been established, many more questions still remain unanswered. When, for example, can companies implement drug-testing programs for safety-related jobs without the approval of the union? Will the implementation of pre-employment drug tests be contingent on the validity of such a test predicting future job performance? Is preemployment testing a violation of Title VII as it relates to questionable results due to dark skin pigmentation?

As Americans become more involved in the war on drugs, employees are likely to be asked to yield more of their privacy rights for detection of drug users. Just how much reduction in privacy will be permitted is yet to be seen.

\section{References}

1. AMOCO Oil Company and OCAW Local 4449. No. 171, DLR A1 (1988). American Standard, 77 LA 7085 (1981).

2. CFS Continental Inc., 86-1, ARB 3293, (1986).

3. Colosi, M.L. “The Labor Relations of Substance Abuse." Labor Law Joumal (October 1989), pp. 642-653.

4. Cone, L. A. "Public Policies Against Drug Use: Paperworkers v. Misco." Labor Law Journal (April 1989), pp. 243-247.

5. Copeland v. Philadelphia Police Dept. No. 49 DLR A-1 (1988).

6. Caruso v. Ward. No. 217 DLR A-5, (1987).

7. Denenberg, T.S. \& D.V. Alcohol and Drugs: Issues in the Workplace. Washington, D.C.: BNA Books (1983). 
8. Denenberg, T.S. \& D.V. "Employee Drug Testing and the Arbitrator: What are the Issues?" The Arbitration Journal (1987a), pp. 42, 20.

9. Denenberg, T.S. \& D.V. National Football League Players Association and National Football League Management Council (1987b). (R. Kasher, October 25, 1986). The Arbitration Joumal, pp. 42, 20.

10. Flannery, H.A. "Termination of Employment for Refusal to Submit to a Drug Test." Labor Law Joumal (May 1989), pp. 293-301.

11. Freuderheim, Milton. "Drug Testing." New York Times (January 3, 1990), D1:3.

12. Gampel, J.C. \& Zeese, K.B. “Are Employers Overdosing on Drug Testing?" Business and Society Review (1985), Vol. 55, pp. 34-48.

13. Gatewood, R.D. \& Feild, H.S. Human Resource Selection 2nd Edition. Hinsdale, IL: The Dryden Press (1990).

14. Hartstein, B. A. "Drug Testing in the Work Places: A Primer for Employers." Employee Relations Law Journal (1987) Vol. 12, pp. 577-604.

15. Horton, N. "Drugs in the Work Place." Management Review (1987), pp. 5-6.

16. Individual Employment Rights Manual. Washington, D.C.: Bureau of National Affairs, Inc. (1989).

17. Johnson-Batman Co. 295 NLRB, No. 26 (1989).

18. Jones v. McKenzie. 628 F. Supp 1500 (1986).

19. Koven, A.M. \& Smith, S. Just Cause: The Seven Tests. San Francisco, CA: Coloracre Publication Inc. (1985).

20. Kroger Company, 1340 LA 4731 (1986).

21. Masi, D. "Company Response to Drug Abuse From AMA's Nationwide Survey." Personnel (March 1987), pp. 40-46.

22. Material Services Corporation and International Brotherhood of Teamsters Local 330 FMSC. 94 LA 37 (1989).

23. National Treasury Employees Union v. Von Raab. No. 54 DLR A-7 (1989).

24. Patchoque-Medford Congress of Teachers $v$. Board of Education of the PatchoqueMedford Union Free School District. No. 156 DLR A3-5 (1987).

25. Phelps Dodge Copper Products Co. and International Brotherhood of Electrical Workers Local 583, FMSC. 94 LA 393 (1990).

26. Schmerber v. California 384 US 757 (1966).

27. Skinner v. Railway Labor Executives Association. No. 54 DLR A-4 (1989). 
28. Star Tribune. 295 NLRB No. 63 (1989).

29. Stone Container Corp. and United Paper Workers Local 531, FMCS. 91 LA 1187 (1988).

30. Taylor v. O'Grady. No. 198 DLR A-9 (1987).

31. Texas Utility Generating Company. No. 82 LA 6 (1983).

32. Union Plaza Hotel. 88 LA 528 (1988).

33. Ver Ploeg, C. "Drug Testing in the Workplace." The Bench \& Bar of Minnesata (1986), pp. 14-20.

34. Verespej, M.A. "Drug Testing: Emerging Set of Rules." Industry Week, Vol. 23 (1987), pp. 20-21.

35. Way, P.K. “Divergent Organizational Responses to Substance Abuse." Labor Law Journal (April 1987), pp. 521-526.

36. Wilson, C.W. "From AIDS to Z: A Primer for Legal Issues Concerning AIDS, Drug Testing, and Alcohol in the Workplace." The Labor Lawyer (1987), pp. 640-674.

37. Wynns, P.A. "A Profile of Grievance Arbitration Cases" The Arbitration Journal, Vol. 34 (1979), pp. 19-27.

38. "Wyoming Court is Second to Allow AMOCO Drug Program to Proceed Until Arbitration." Daily Labor Report 226 (1986), A-6. 